\title{
Prototype Alat Monitoring Vital Sign Pasien Rawat Inap Menggunakan Wireless Sensor Sebagai Upaya Physical Distancing menghadapi Covid-19
}

\author{
Anggi Zafia \\ Fakultas Informatika, Institut Teknologi Telkom Purwokerto \\ Jl. D.I Panjaitan 128 Purwokerto, Jawa Tengah, Indonesia \\ ${ }^{\# 1}$ zafia@ittelkom-pwt.ac.id
}

Accepted on 21-05-2020

\begin{abstract}
Abstrak
Pasien stoke yang menjalani rawat inap di rumah sakit harus dicek kesehatannya secara berkala yaitu diukur suhu tubuh, tekanan darah, oksigen dalam darah, dan denyut jantungnya. Padahal dunia sedang mengalami pandemi virus corona yang menyerang sistem pernapasan dan belum ditemukan obat atau vaksinnya. Badan kesehatan dunia WHO menerapkan protokol yang dapat mencegah penularan virus lebih banyak salah satunya physical distancing atau menjaga kontak fisik secara langsung. Sehingga perawat harus melakukan pengecekkan kondisi pasien tersebut tanpa bertemu langsung pasien di dalam kamar perawatan. Maka dibuat alat yang dapat mendeteksi kondisi pasien secara simultan tanpa kontak langusng guna menjaga kualitas hidup dan status kesehatan pasien. Hasil dari penelitian ini berupa prototipe perancangan sistem yang terdiri dari node dan sink/koordinator. Node mengolah dan mengirimkan data sensor yang kemudian diterima oleh koordinator dan ditampilkan dalam jaringan lokal maupun internet. Dalam pengukuran suhu terdapat selisih antara pengukuran prototipe dengan metode manual maupun prototipe dengan metode digital sebesar $0.17^{\circ} \mathrm{C}$. Selisih pengukuran pulse antara prototipe dengan metode manual sebesar 0.7 BPM, prototipe dengan metode digital sebesar 3.3 BPM. Dan pengukuran SpO2 mempunyai selisih antara pengukuran prototipe dengan metode digital sebesar $0 \%$. Berbeda pada pengukuran tekanan darah yang terlihat jelas selisih antara ketiga pengukuran tersebut yaitu sebsesar 3-9 $\mathrm{mmHg}$. Ini disebabkan beberapa faktor seperti adanya arus tegangan yang melemah karena energi baterai yang semakin berkurang atau karena masih terdapat sedikit kesalahan prosedur dalam penggunaan alat.
\end{abstract}

Keywords: vital sign, wireless sensor, pasien, covid-19, physical distancing

\section{PENDAhuluan}

$\mathbf{T}$ eknologi sensor yang memudahkan manusia dalam sistem otomasi, tumbuh cepat merambah ke segala aspek kehidupan manusia. Pesatnya pertumbuhan sensor tersebut menjadikan wireless sensor network (WSN) populer di berbagai domain seperti rumah tangga, industri, hingga kesehatan. Penerapan wireless sensor network atau jaringan sensor nirkabel lebih fleksibel dan menguntungkan karena memungkinkan layanan otomasi dan komunikasi jarak jauh tanpa menggunakan kabel. Jaringan sensor nirkabel dapat digunakan untuk mengukur lingkungan sekitar (ambient) seperti kelembaban, suhu, intensitas cahaya, pemantauan 
polusi, pengukuran energi, serta untuk mengendalikan aktuator, dan pencahayaan. Jaringan sensor nirkabel dalam dunia kesehatan dapat digunakan untuk memantau kondisi pasien dengan cara mengukur denyut jantung, tekanan darah, suhu tubuh, glukosa dalam darah oleh node sensor yang dikirim ke server atau sink [1]. Komunikasi jarak jauh tanpa menggunakan kabel dan membutuhkan daya baterai yang kecil merupakan cara yang paling praktis dan efisien untuk mengumpulkan berbagai parameter dan informasi yang diperlukan dengan sistem otomasi.

Pasien stoke yang menjalani rawat inap di rumah sakit harus dicek kesehatannya secara berkala yaitu diukur suhu tubuh, tekanan darah, oksigen dalam darah, dan denyut jantungnya. Perawat harus melakukan pengecekkan kondisi pasien tersebut setiap saat. Hal ini membuat perawat secara sering akan menemui pasien di dalam kamar perawatan. Sehingga pasien akan mengalami kontak fisik secara langsung dengan perawat. Padahal dunia sedang mengalami pandemi Covid-19 yaitu wabah yang disebabkan oleh Virus Corona atau severe acute respiratory syndrome coronavirus 2 (SARS-CoV-2) yang menyerang sistem pernapasan dan belum ditemukan obat atau vaksinnya. Menurut peta persebaran John Hopkins University \& Medicine Coronavirus Ressorce Center [4] tanggal 30 april 2020, virus Covid-19 sudah menginveksi 3,218,430 jiwa dan terkonfirmasi meninggal dunia sebanyak 228,625 di seluruh dunia. Di Indonesia [5], pada tanggal yang sama, virus ini menyerang penderitanya sebanyak lebih dari 10.000 orang, dan meninggal dunia sebanyak 792 jiwa dalam waktu 2 bulan. Badan kesehatan dunia WHO menerapkan protokol yang dapat mencegah penularan virus lebih banyak. Yaitu, sering mencuci tangan dengan sabun, penggunaan masker, dan physical distancing atau menjaga kontak fisik secara langsung. Untuk menjalankan salah satu protokol kesehatan yaitu physical distancing atau kontak langsung antara pasien dengan perawat, maka bisa menggunakan alat yang dapat mendeteksi kondisi pasien secara simultan tanpa kontak langusng guna menjaga kualitas hidup dan status kesehatan pasien. Sehingga proses monitoring kesehatan pasien tetap dapat dilakukan dan pasien akan tetap merasa aman. Penelitian ini bertujuan membuat alat monitoring vital sign menggunakan wireless sensor untuk menjalankan protokol physical distancing guna menguragi resiko penularan Covid-19.

\section{TINJAUAN PUSTAKA}

Riset tentang monitoring vital sign bukan suatu hal yang baru melainkan telah ada penelitian mengenai pemantauan pada vital sign yang dilakukan oleh beberapa peneliti diantaranya yang dibuat oleh M. M. Baig, et al. [1], mengembangkan sistem monitoring vital sign untuk pasien di rumah sakit menggunakan pendekatan multifaktorial dan holistik menggunaan model fuzzy untuk mengetahui indikasi kesehatan yang dialami. Contohnya, hipotensi didefinisikan sebagai pasien dengan tekanan darah yang rendah. Sistem tersebut mengukur tekanan darah, denyut jantung, saturasi oksigen dan suhu pasien yang dipantau secara real-time dan menghasilkan tingkat akurasi pengukuran sebesar 95,83\%. M. Shu, et al. [2], mengembangkan sistem pemantau kesehatan pasien dengan menggunakan dua sensor yaitu sensor detak jantung (heart rate) dan sensor tingkat pernafasan (repiratory rate). Hasil sensing disimpan dalam server Cloud dengan memanfaatkan jaringan WIFI sebagai transfer datanya. Cloud dapat menyaring, menganalisis, dan menghitung data monitoring vital sign yang dapat berubah secara dinamis. Perubahan data tersebut kemudian ditampilkan pada smartphone berbasis Android. Pada penelitian ini, antara data dari perangkat pengirim dan perangkat penerima dibandingkan dan keduanya menghasilkan data yang sama. I. E. Berliandhy, et al. [3], membuat alat monitoring pendeteksi sinyal EKG, detak jantung, suhu, dan tekanan darah yang diambil dari tubuh pasien. Hasil deteksi sensor berupa data mentah yang dikirim secara serial melalui ZigBee ke dua perangkat host komputer yang berbeda, sehingga data pemantauan tanda vital pasien dapat dilihat dari jarak jauh. Pada penelitian ini, antara data dari perangkat pengirim dan perangkat penerima dibandingkan dan keduanya mempunyai error pengukuran tekanan darah sebesar $60,946 \%$, suhu $0,085 \%$, dan denyut nadi $0,986 \%$. Kesalahan tersebut disebabkan oleh data ekstensif saat terjadi pengiriman dan penerimaan data.

Pada penelitian ini akan menyajikan sebuah perancangan alat untuk mendeteksi tanda vital manusia dengan empat sensor yaitu sensor suhu, denyut nadi, $\mathrm{SpO} 2$, dan tekanan darah dengan model komunikasi jaringan nirkabel berupa perangkat xbee. Kordinator akan menerima dan menyimpan transfer data dari sensor yang kemudian dapat ditampilkan pada jaringan website dan browser smartphone. 


\section{A. Wireless sensor network}

Wireless sensor network (WSN) adalah suatu sistem terpadu yang terdiri dari sekelompok node / modul sensor yang terdistribusi dan terhubung secara nirkabel pada suatu topologi jaringan dan berfungsi untuk mengekstrak berbagi informasi untuk diolah sesuai bidang aplikasinya [6]. Jaringan sensor nirkabel dirancang untuk mendeteksi suatu peristiwa atau fenomena, mengumpulkan dan mengolah data, dan mengirimkan informasi kepada pengguna. Tujuan dari jaringan sensor nirkabel adalah persepsi dan koordinasi, pengumpulan dan pengolahan obyek jangkauan jaringan dan mengirimkan informasi ke pengguna. Dalam telemedis, WSN dikenal dengan WBSN (Wireless Body Sensor Network) [6]. WBSN dilengkapi dengan biosensor yang memungkinkan pengawasan medis secara berkelanjutan dan menyediakan akses ke data medis dalam kegiatan sehari-hari pada subjek penelitian.

WBSN kemudian dikembangkan untuk monitoring dan kontrol fisiologis secara real-time pada pasien di lapangan. Sensor yang dipakai dapat berupa sensor suhu tubuh, sensor tekanan darah (Sphygmomanometer), Sensor Pulse dan Oksigen dalam darah (SpO2), Sensor Airflow (pernafasan) dan lain-lain. Sensor-sensor tersebut dapat mendeteksi sejak dini kondisi kesehatan yang akan dialami kemudian.

\section{B. Arduino}

Arduino merupakan platform berbasis open-source yang di buat untuk memudahkan user dalam membuat perangkat elektronik mikrokontroler [8]. Seorang pemula dapat lebih mudah dalam merancang perangkat berbasis mikrokontroler karena desain dari Arduino yang bisa dipasang/dihubungkan dengan modul-modul lain seperti xbee, sensor, dan layar LCD melalui media yang disebut shield. Arduino adalah mikrokontroler yang terdiri dari hardware dan software. Hardware berfungsi sebagai papan input dan output sedangkan software berupa Integrated Development Environment (IDE) [8] yang digunakan untuk menulis bahasa pemrograman.

\section{Xbee}

Xbee adalah modul komunikasi wireless yang didesain dengan menggunakan protokol dari Zigbee. Zigbee merupakan suatu teknologi nirkabel yang mengacu pada standar IEEE 802.15.4. Penggunaan dari teknologi zigbee bertujuan untuk transfer data secara nirkabel dengan transmisi data dan konsumsi daya rendah dibandingkan dengan Bluetooth atau modul wireless lainnya. Penerapan teknologi Zigbee telah banyak digunakan diberbagai sektor, seperti sektor insustri, pertanian, atau lingkungan perhutani sebagai pengendalian hutan guna mendapatkan informasi cuaca sekitar, kelembapan, tingkat suhu, dan lain sebaginya. Informasi tersebut berasal dari data yang ditransmisikan secara wireless oleh adanya teknologi Zigbee sehingga hutan dapat terlindungi dari bahaya seperti adanya kebakaran atau akibat buruk lainnya. Dalam dunia kesehatan Zigbee digunakan untuk memantau kondisi kesehatan pasien [9].

\section{Sensor suhu}

Suhu atau temperatur dapat diukur dengan sebuah sensor. Ada berbagai macam sensor yang dapat digunakan untuk mendeteksi suhu baik suhu benda maupun suhu ruangan. Pemilihan sensor bergantung pada sesuatu yang akan diukur, karena setiap sensor suhu mempunyai temperature kerja yang berbeda-beda. Pengukuran suhu pada suatu benda dapat menggunakan sensor jenis Integrated Circuit (IC). Maka IC tipe LM35 lebih tepat digunakan untuk penelitian ini. Sensor LM35 bekerja dengan mengubah besaran suhu menjadi besaran tegangan. Sensor suhu LM35 [10] mempunyai parameter bahwa setiap kenaikan suhu sebesar $1{ }^{\circ} \mathrm{C}$ maka tegangan keluarannya akan naik sebesar $10 \mathrm{mV}$ dengan batas maksimal keluaran sensor adalah $1,5 \mathrm{~V}$ pada suhu $150^{\circ} \mathrm{C}$.

\section{E. Pulse Oximetry}

Sensor pulse oximetry menggunakan metode pengukuran non-invasif [7]. Sensor yang digunakan pada penelitian menggunakan sensor tipe MAX30100. Sensor ini dapat mendeteksi detak nadi dan SpO2 pasien.

\section{F. Sensor Tekanan Darah}

Sensor tekanan MPX5050 DP [11] adalah sensor tranduser piezoresistif yang terbuat dari bahan silicon yang dapat dipakai untuk sebuah mikrokontroler. Sensor ini dilengkapi dengan chip signal conditioned, temperature compensated, dan calibrated. 


\section{G. Ethernet Shield}

Arduino ethernet shield merupakan modul yang berfungsi menghubungkan Arduino board dengan jaringan internet. Ethernet shield menggunakan chip yang didasarkan pada Wiznet W5100 [12]. Modul ini dapat berfungsi sebagai web server maupun client dalam jaringan.

\section{METODE PENELITIAN}

Beberapa langkah jalannya penelitian diantaranya meliputi studi literatur, identifikasi masalah, perancangan sistem, pengujian sistem, pengambilan data, dan pembuatan laporan. Bentuk diagram alir pada penelitian ini dapat di lihat pada Gambar 1. Langkah pertama studi literatur, bertujuan untuk mempelajari beberapa penelitian terkait sistem monitoring vital sign yang pernah dilakukan sebelumnya. Dengan mengetahui dan mempelajari pustaka penelitian yang sudah ada sebelumnya maka penelitian selanjutnya dapat ditentukan arah dan tujuan dari penelitian yang akan dilakukan. Kedua identifikasi masalah, merupakan cara untuk membandingkan berberapa studi literatur yang telah dipelajari sebelumnya kemudian melakukan observasi untuk mencari studi kasus atau sebuah masalah yang ada saat ini terkait dengan sistem monitoring vital sign. Setelah menemukan topik dari sebuah studi kasus, langkah ketiga adalah memulai dengan perancangan sebuah sistem sebagai pendukung dalam memecahkan masalah tersebut. Sistem yang dibuat berupa sensorsensor yang akan mendeteksi tanda vital (vital sign) suatu objek berupa manusia dengan model koneksi nirkabel (wireless body area network). Sehingga akan dibutuhkan hardware dan software sebagai satu kesatuan terciptanya suatu sistem yang diharapkan.

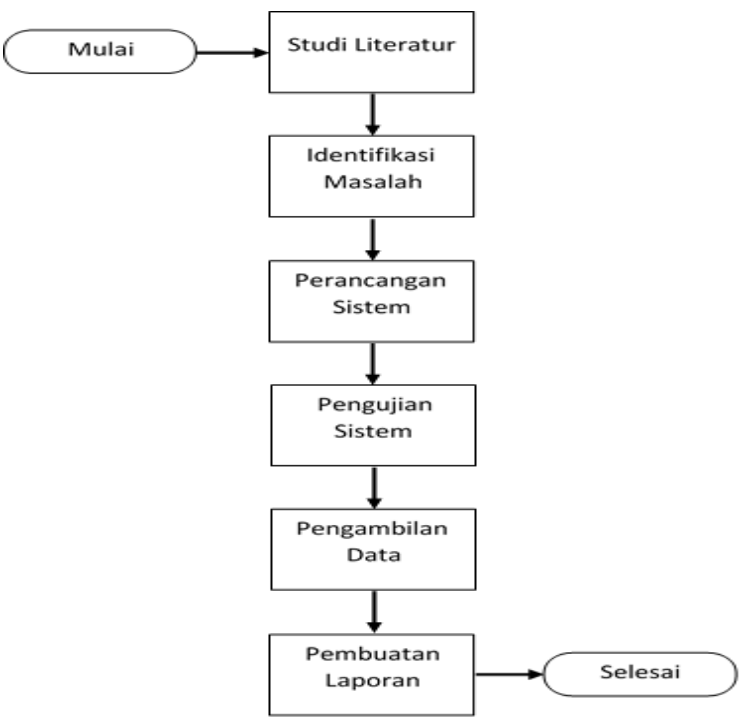

Gambar 1. Diagram alir langkah-langkah penelitian

\section{A. Perangkat Keras (Hardware)}

Perancangan hardware pada penelitian ini terpisah dalam dua bagian. Layaknya konsep wirelses sensor network, hardware yang akan dibangun terdiri dari node dan sink. Node sensor akan mendeteksi vital sign pasien yang kemudian diolah dan dikirim ke kordinator/sink. Sink akan menerima data dari setiap node dan menampilkannya pada sebuah layar monitor menggunakan browser komputer atau smartphone. Perancangan hardware pendeteksi vital sign pada penelitian ini menggunakan mikrokontroler Arduino board yang dihubungkan dengan sensor yang sudah tersedia dipasaran dan kemudian dihubungkan menggunakan Xbee sebagai media koneksi jaringannya. 


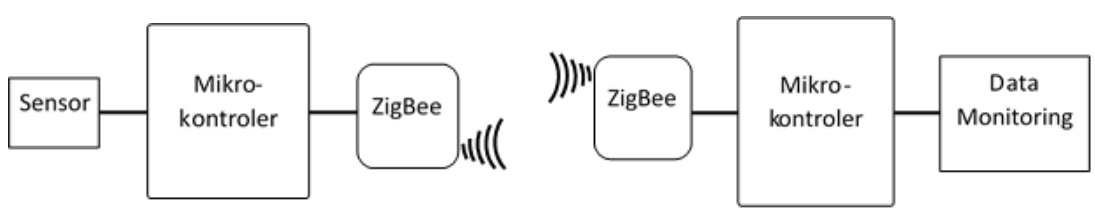

Gambar 2. Diagram blok Perancangan WSN vital sign

\section{B. Perangkat Lunak (Software)}

Perangkat lunak yang digunakan adalah IDE arduino untuk memporgram hardware mikrokontroler Arduino. IDE merupakan kependekan dari Integrated Developtment Enviroenment, atau secara bahasa merupakan lingkungan terintegrasi yang digunakan untuk melakukan pengembangan. Dan software tambahan lainnya berupa Teks Editor Notepad++, Web server XAMPP, dan Bootstrap.

\section{HASIL DAN PEMBAHASAN}

Penelitian ini menghasilkan alat yang digunakan sebagai media untuk monitoring vital sign. Alat yang dibangun berupa prototipe yang terdiri dari hardware dan software. Node sensor (Gambar 3) mempunyai beberapa komponen yaitu Arduino Mega, keypad, sensor-sensor (suhu tubuh, denyut nadi dan saturasi oksigen dalam darah/SpO2, dan tekanan darah), modul Xbee, dan LCD 16x2, tombol on/off, push button start, konektor arus tegangan DC. Perangkat ini berfungsi mengukur serta merekam kondisi pasien berdasarkan tanda vital suhu, denyut nadi \& saturasi oksigen, dan tekanan darah. Data hasil perekaman kemudian ditransfer ke node sink melalui Xbee. Tombol on/off digunakan untuk mnghidupkan dan mematikan perangkat node sensor. Fungsi dari keypad digunakan menginputkan nomor identitas pasien sebelum melakukan perekaman data. Push button Start digunakan untuk memulai pengukuran data. Layar LCD digunakan untuk menampilkan data hasil pengukuran. Dan konektor DC digunakan untuk power supply node sensor yang dapat dihubungkan dengan adaptor maupun baterai dengan arus tegangan 9 Volt. Sedangkan perangkat keras pada node sink (Gambar 4) atau disebut koordinator terdiri dari Arduino Uno, Ethetnet Shield, Xbee Shield, dan modul Xbee. Node sink bertugas menerima data hasil perekaman vital signs pasien yang dikirim dari node sensor. Komunikasi antar keduanya menggunakan protokol zigbee melalui modul Xbee. Data dari node sink selanjutnya diteruskan ke perangkat server untuk disimpan dalam database MySQL.

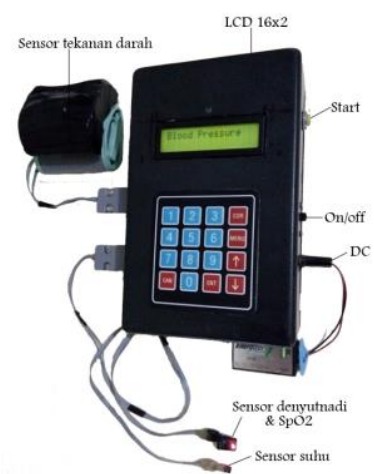

(a)

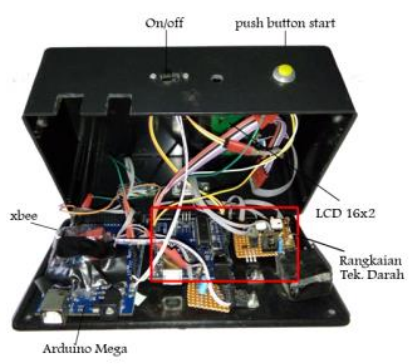

(b)

Gambar 4 Node sensor (a) tampak luar, (b) tampak dalam 


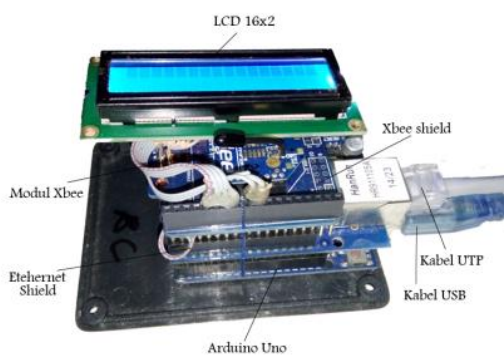

(a)

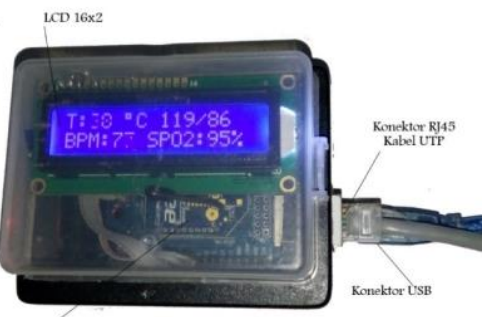

(b)

Gambar 4 Node sink (a) tampak luar, (b) tampak dalam

Setelah selesai melakukan perancangan alat kemudian dilakukan pengujian apakah alat yang telah dibangun dapat menghasilkan output yang sesuai. Pengujian perlu dilakukan untuk mengetahui akurasi data hasil pembacaan dan pengukuran sensor yang dipasang pada tubuh pasien. Apakah hasil pengukuran vital sign dengan menggunakan sensor suhu, denyut nadi, saturasi oksigen (SpO2), dan tekanan darah sudah berjalan dengan baik atau belum. Pengujian dengan cara melakukan perbandingan alat manual, alat digital dan alat prototipe yang dibangun. Alat manual, alat digital maupun alat prototipe diletakkan di tubuh pasien pada posisi bagian tubuh yang sama kecuali tekanan darah. Sensor suhu/termometer diletakkan pada ketiak pasien, sensor denyut nadi dan $\mathrm{SpO} 2$ diletakkan pada ujung jadi pasien, tekanan darah pada alat manual dan digital diletakkan pada lengan pasien, sedangkan alat prototipe diletakkan pada pergelangan pasien. Pengujian dengan mengukur vital sign dibantu tenaga medis dengan prosedur yang sesuai agar menghasilkan data yang valid. Data hasil pengukuran dapat dilihat pada Tabel 1.

TABLE I

PERBANDINGAN PENGUKURAN Alat

\begin{tabular}{|c|c|c|c|}
\hline Sensor & Manual & Digital & Prototipe \\
\hline Suhu 1 & 36 & 36 & 35.8 \\
\hline Suhu 2 & 36 & 36.1 & 36 \\
\hline Suhu 3 & 36.2 & 36.1 & 35.9 \\
\hline Rata-rata Suhu $\left({ }^{\circ} \mathrm{C}\right)$ & 36.07 & 36.07 & 35.9 \\
\hline Tek.Darah 1 & $120 / 80$ & $128 / 85$ & $119 / 83$ \\
\hline Tek.Darah 2 & $90 / 70$ & $94 / 69$ & $93 / 67$ \\
\hline Tek.Darah 3 & $120 / 70$ & $117 / 73$ & $117 / 72$ \\
\hline $\begin{array}{r}\text { Rata-rata Tek.Darah } \\
(\mathbf{m m H g})\end{array}$ & $110 / 73$ & $113 / 76$ & $110 / 74$ \\
\hline Pulse 1 & 81 & 84 & 80 \\
\hline Pulse 2 & 78 & 81 & 76 \\
\hline Pulse 3 & 74 & 76 & 75 \\
\hline $\begin{array}{r}\text { Rata-rata Pulse } \\
\text { (BPM) }\end{array}$ & 77.7 & 80.3 & 77 \\
\hline SpO2 1 & - & 97 & 97 \\
\hline SpO2 2 & - & 97 & 96 \\
\hline SpO2 3 & - & 96 & 97 \\
\hline Rata-rata SpO2 (\%) & & 96.7 & 96.7 \\
\hline
\end{tabular}

Pada Tabel 1 menunjukkan bahwa pengukuran suhu, denyut nadi (pulse), dan saturasi oksigen ( $\mathrm{SpO} 2)$ secara manual, digital, maupun menggunakan prototipe terdapat perbedaan atau selisih antara pengukuran 
satu dengan yang lainnya tetapi angkanya tidak terlalu signifikan. Pada pengukuran suhu terdapat selisih antara pengukuran prototipe dengan metode manual maupun prototipe dengan metode digital sebesar $0.17^{\circ} \mathrm{C}$. Selisih pengukuran pulse antara prototipe dengan metode manual sebesar 0.7 BPM, prototipe dengan metode digital sebesar 3.3 BPM. Dan pengukuran SpO2 mempunyai selisih antara pengukuran prototipe dengan metode digital sebesar $0 \%$. Berbeda pada pengukuran tekanan darah yang terlihat jelas selisih antara ketiga pengukuran tersebut yaitu sebsesar 3-9 $\mathrm{mmHg}$. Ini disebabkan beberapa faktor seperti adanya arus tegangan yang melemah karena energi baterai yang semakin berkurang atau karena masih terdapat sedikit kesalahan prosedur dalam penggunaan alat. Data Tabel 1 kemudian direpresentasikan pada Gambar 3.

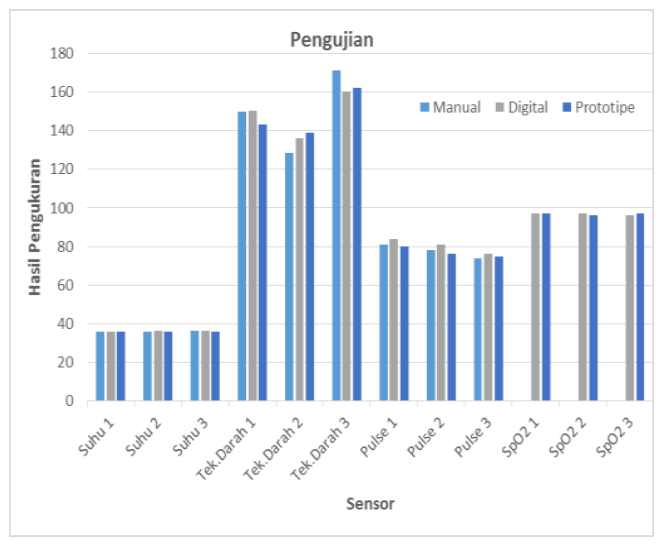

Gambar 3. Grafik pengujian metode manual, digital, dan prototipe

Selain pengujian sensor, pengujian komunikasi antar node dan koordinator juga perlu dilakukan guna mengetahui apakah data yang diterima (koordinator) sesuai dengan data yang dikirim (node sensor). Dari pengujian komunikasi dengan modul Xbee dihasilkan data yang sama persis antara node dan sink/koordinator. Data yang telah diterima koordinator kemudian diinput untuk disimpan ke dalam database MySQL menggukanan bantuan modul ethernet shield yang tersambung ke mikrokontroler arduino. Ethernet shield berguna sebagai web server maupun client. Namun pada penelitian ini, ethernet shield bertindak sebagai client yang kemudian dihubungkan dengan gateway/komputer dan dikoneksi ke jaringan internet. Dari alur koneksi yang sedemikian rupa sehingga monitoring vital sign pasien bisa dilakukan dengan mengakses datanya melalui media internet. Web monitoring vital sign tersebut diimplementasikan dalam tampilan pada Gambar 4.

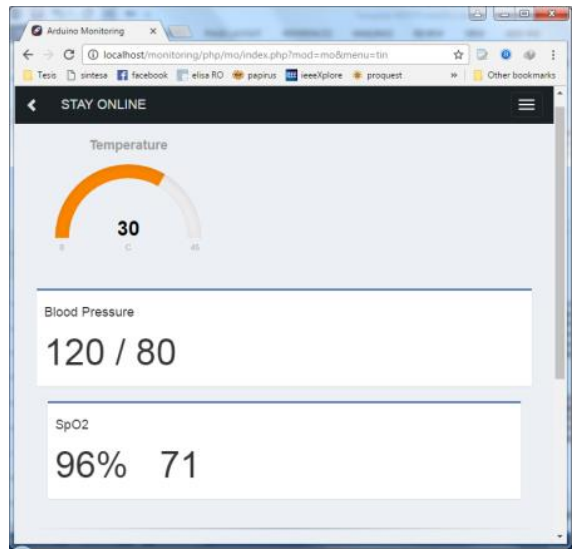

Gambar 4. Tampilan web monitoring vital sign

Gambar 4 merepesentaikan data vital sign pasien. Dengan tampilan web tersebut, maka tenaga medis atau stakeholder yang lainnya dapat mengakses data kapanpun dan dimanapun. Bagi seorang perawat data 
tersebut berguna untuk melakukan tindakan selanjutnya pada pasien dengan penanganan yang lebih cepat. Seperti telah diketahui pada umumnya, terkadang seorang dokter tidak selalu berada didekat pasien, sehingga tugasnya digantikan oleh perawat. Perawat dalam melakukan tindakan tertentu harus ada izin seorang dokter sehingga seorang perawat perlu melaporkan detail keadaan pasien saat itu. Maka dengan melihat data vital sign yang bisa diakses oleh dokter melaui internet, penanganan pasien seperti pemberian obat pada pasien dapat dilakukan sesuai dengan kondisi pasien saat itu.

\section{KESIMPULAN}

Penelitin ini telah membahas pengembangan alat monitoring vital sign untuk memantau pasien dalam mengukur suhu tubuh, tekanan darah, denyut nadi dan $\mathrm{SpO}$. Hasil dari penelitian ini berupa prototipe sistem monitoring kesehatan berbasis wireless yang dapat diakses melalui jaringan internet dan telah di implementasikan tanpa menggunakan aritektur yang komplek. Sensor pendeteksi kesehatan ini dapat selalu dipasang pada pasien penderita stroke tanpa merasa terganggu oleh banyaknya kabel yang menempel pada tubuh seperti alat konvensional. Hasil pengukuran suhu terdapat selisih antara pengukuran prototipe dengan metode manual maupun prototipe dengan metode digital sebesar $0.17^{\circ} \mathrm{C}$. Selisih pengukuran pulse antara prototipe dengan metode manual sebesar 0.7 BPM, prototipe dengan metode digital sebesar 3.3 BPM. Dan pengukuran $\mathrm{SpO} 2$ mempunyai selisih antara pengukuran prototipe dengan metode digital sebesar $0 \%$. Berbeda pada pengukuran tekanan darah yang terlihat jelas selisih antara ketiga pengukuran tersebut yaitu sebsesar 3-9 mmHg. Ini disebabkan beberapa faktor seperti adanya arus tegangan yang melemah karena energi baterai yang semakin berkurang atau karena masih terdapat sedikit kesalahan prosedur dalam penggunaan alat. Penelitian selanjutnya diharapkan dapat memberikan kenyamanan pada pasien, keandalan pada node sensor, keamanan jaringan, dan antarmuka aplikasi yang user friendly.

\section{DAFTAR PUSTAKA}

[1] M. M. Baig, H. GholamHosseini and M. J. Connolly, "Integrated vital signs monitoring system using ubiquitous devices: Multiple physical signs detection and decision support for hospitalized older adults," 2015 37th Annual International Conference of the IEEE Engineering in Medicine and Biology Society (EMBC), Milan, 2015, pp. 1219-1222

[2] M. Shu, M. Tang, M. Yang and N. Wei, "The Vital Signs Real-Time Monitoring System Based on Internet of Things," 2017 4th International Conference on Information Science and Control Engineering (ICISCE), Changsha, 2017, pp. 747-751

[3] I. E. Berliandhy, A. Rizal, S. Hadiyoso and R. Febyarto, "A multiuser vital sign monitoring system using ZigBee wireless sensor network," 2016 International Conference on Control, Electronics, Renewable Energy and Communications (ICCEREC), Bandung, 2016, pp. 136-140

[4] John Hopkins University \& Medicine Coronavirus Ressorce Center, [Online]. Available:https://coronavirus.jhu.edu/map.html. [Accessed 30 April 2020].

[5] Gugus Tugas Percepatan Penanganan COVID-19, [Online]. Available: https://www.covid19.go.id [Accessed 30 April 2020].

[6] Sanjay Sharma, Anoop Lal Vyas, Bhaskar Thakker, "Wireless Body Area Network for Health Monitoring," IEEE, 2011.

[7] Casanova, Hernandez, M., Sanchez, A., Garcia, I., \& De torres, J. (2006), "Twenty-four-hour ambulatory oximetry monitoring in COPD patients with moderate hypoxemia," Des. 2006.

[8] Arduino Developers, [Online]. Available: https://www.arduino.cc/en/Main/arduinoBoardUno. [Accessed 13 Januari 2019].

[9] Digi International@ Inc., "XBee® 802.15.4," [Online]. Available: http://www.digi.com/products/xbee-rfsolutions/modules/xbee-series1-module. [Accessed 21 Agust. 2015].

[10] Texas Instruments, [Online]. Available: http://www.ti.com/lit/ds/symlink/lm35.pdf. [Accessed 25 Maret 2015].

[11] Motorola Semiconductor Technical Data, [Online]. Available: www.partsprocurement.com/itemimages/ MPX5050DP.pdf. [Accessed 27 Februari 2016].

[12] Arduino Developers, [Online]. Available: https://www.arduino.cc/en/Main/ ArduinoEthernetShield. [Accessed 13 Oktober 2019]. 